\title{
Determinant of University Students' Choices and Preferences of Agricultural Sub-Sector Engagement in Cameroon
}

\author{
Cynthia J. Mkong 1,*, Tahirou Abdoulaye ${ }^{2}$, Paul Martin Dontsop-Nguezet ${ }^{3}$, Zoumana Bamba ${ }^{4}$, \\ Victor Manyong ${ }^{5}\left(\mathbb{D}\right.$ and Godlove Shu ${ }^{1}$
}

1 Department of Agricultural Economics and Agribusiness, University of Buea, P.O. BOX 63, Buea, Cameroon; shugodlove58@yahoo.com

2 Social Science and Agribusiness, International Institute of Tropical Agriculture (IITA), B.P. 320, Bamako, Mali; T.Abdoulaye@cgiar.org

3 Social Science and Agribusiness, International Institute of Tropical Agriculture (IITA), Kalemie, Democratic 570, Democratic Republic of the Congo; P.Dontsop@cgiar.org

4 Country Representative, International Institute of Tropical Agriculture (IITA), Kinshasa, Democratic 4163, Democratic Republic of the Congo; Z.Bamba@cgiar.org

5 Social Science and Agribusiness, International Institute of Tropical Agriculture (IITA), P.O. BOX 34441, Dar es Salam, Tanzania; v.manyong@cgiar.org

* Correspondence: mkongcynthiajeh@gmail.com

Citation: Mkong, C.J.; Abdoulaye, T.; Dontsop-Nguezet, P.M.; Bamba, Z.;

Manyong, V.; Shu, G. Determinant of

University Students' Choices and

Preferences of Agricultural

Sub-Sector Engagement in Cameroon Sustainability 2021, 13, 6564. https:// doi.org/10.3390/su13126564

Academic Editor: Donato Morea

Received: 12 April 2021

Accepted: 26 May 2021

Published: 9 June 2021

Publisher's Note: MDPI stays neutral with regard to jurisdictional claims in published maps and institutional affiliations.

Copyright: () 2021 by the authors. Licensee MDPI, Basel, Switzerland. This article is an open access article distributed under the terms and conditions of the Creative Commons Attribution (CC BY) license (https:// creativecommons.org/licenses/by/ $4.0 /)$.
Abstract: Although the agri-food sector has a huge potential to offer attractive employment opportunities for Africa's burgeoning youth, a negative perception of agriculture persists among Cameroonian youths, such as in many other African countries. The paper assesses the determinants of university students' choices and preferences for agricultural sub-sector engagement in Cameroon. A multistage random sampling technique was used to select 550 students from two state universities. We used the SWOT analysis to evaluate students' perceptions of challenges and opportunities within the agricultural sector in Cameroon, the binomial probit analysis to assess the determinants of students' choices of agriculture as a university major, and an ordered probit analysis to evaluate the determinants of students' preferences of agricultural sub-sector engagement. Findings reveal that choice of agriculture as a university major is significantly determined by sex, pre-university farming experience, pre-university academic background, mother's level of education, and household income. Likewise, preference of agricultural sub-sector engagement is significantly determined by the student's level of study and location of a childhood home. Improving the attractiveness of, and working conditions in, the agricultural sector could increase youth engagement in agribusiness and rural economic activities. The results also reinforce the need to increase household income in Cameroon, as this could lift families out of poverty and offer them more economic opportunities. Policies that regulate levels of education can equally be used to allocate human resources into different agricultural sub-sectors, subject to felt needs.

Keywords: youth; agriculture; university student; choice; preference; sub-sector engagement; Cameroon

\section{Introduction}

Agriculture remains an essential driver of pro-poor growth and the largest employer in Africa, even in the context of off-farm diversification [1-4]. The agricultural sector plays a crucial role in improving rural economies and reducing poverty in Africa [5]. In Africa, $61 \%$ of the entire population is under 24 years of age, representing current and future youth cohorts of a sobering magnitude [6,7]. The agri-food sector is therefore thought to have a huge potential to offer attractive employment opportunities for Africa's burgeoning youth [8-10] and is crucial to addressing the disproportionately high levels of youth unemployment, underemployment, and poverty [10,11].

Agriculture is the spine of Cameroon's economy, employing up to 70\% of its workforce and contributing $42 \%$ of its Gross Domestic Product (GDP), 30\% of its export revenue, and 
$23 \%$ of its added value $[4,12]$. Cameroon produces a variety of agricultural commodities both for export and for domestic consumption. However, the agricultural sector remains underdeveloped with the predominance of subsistence farming characterized by low yields per hectare, low rates of modern technology adoption, high vulnerability to climate, and weather risks, among others.

The contribution of the youth to both agricultural and economic development in Africa can hardly be overestimated. Yet, a majority of African youths today do not have stable economic opportunities [13,14]; of Africa's nearly 420 million youth aged 15-35, 33\% are unemployed and discouraged, another $33 \%$ are vulnerably employed, and only $16 \%$ are in wage employment $[13,15]$. Again, over $70 \%$ of these youths subsist on less than US $\$ 2$ per day, and the incidence of decent work deficits and poverty is particularly high among young rural women [16]. These poor prospects for young people partly arise from the rural economic stagnation observed in many developing countries. Africa's youth problem, therefore, consists not only of officially registered unemployment, but also of official and hidden underemployment, vulnerable employment, and discouragement $[17,18]$.

Youth in this study was defined using the definition of the African Union Charter that considers the age brackets 15-35. These youth possess qualities and strengths that could enhance agricultural productivity. However, a negative perception of agriculture persists among Cameroonian youth as it does among the youth of many African countries [19-26]. Agriculture in its present state appears to be so unattractive to young people that they are turning away from agricultural or rural futures $[23,27-31]$. This unattractiveness results from a growing divide between their economic, social, and lifestyle aspirations and the opportunities that agriculture offers [32]. Particularly for rural youth, their dream of a "good life" often lies far away from the rural areas. A key impediment to youth involvement in agriculture has therefore been chronic government neglect of small-scale agriculture and rural infrastructure [12,27]. The downgrading of farming and rural life, coupled with a lack of role models among young farmers, also appear as likely reasons for young Africans' increasingly reluctance to pursue agriculture-based livelihoods [32-34]. Taking into account the sparse job opportunities, very low and unpredictable remuneration, and harsh working conditions, it is indeed not surprising that youth rarely mention farming as a "good job" [1,35].

Recognizing agriculture as an attractive option is even more challenging when economic and social restrictions related to access to productive resources are taken into account. Limited access of African youth to knowledge, information, and education, among others, has been identified as a major impediment to agricultural productivity in the developing world in general, and Africa in particular [11,36-39]. Increased rural-urban migration [40], falling levels of youth involvement in agricultural activities, and their unwillingness to undertake education in the field of agriculture, among others, further constrain agricultural development on the continent [6]. Consequently, in most African countries, the agricultural sector has experienced a shortage of qualified graduates to address skill gaps, transform the sector, and increase its performance in recent years [6,26,31,41]. More tragic is the fact that a majority of the few who brave the odds to major in an agriculture-related discipline fail to choose a career in primary agricultural production and transformation. These graduates prefer off-farm jobs within the sector, such as consultancy, marketing, teaching, or extension. This high concentration of graduates in the tertiary sub-sector has led to heavy competition for the often few jobs available, thus increasing the rates of youth underemployment and unemployment. This unfortunate situation further discourages African youth from considering agriculture as a career option. This diagnosed falling youth interest, especially in the primary production and transformation sub-sectors, is a threat not only to Africa's food security but that of the world, given that Africa contributes a significant quota to global food production [41]. Evaluating youth's choices and preferences of agricultural sub-sector engagement will help inform policy-making geared towards revamping the declining youth interest in agriculture and rural economic activities, as well as curbing youth unemployment, underemployment, and discouragement in Africa. This paper as- 
sesses the determinants of university students' choices and preferences of agricultural sub-sector engagement in Cameroon (the sub-sectors include primary production, transformation, and agriculture-related services). Specifically, we determine students' perception of inherent opportunities as well as the challenges inherent to Cameroon's agricultural sector; assess the determinants of university students' choice of agriculture as a university major in Cameroon; and assess the determinants of students' preferences for particular sub-sectors on Cameroon's agricultural value chain. The three sub-sectors refer to primary agricultural production, agricultural transformation, and agriculture-related services.

We hypothesize that students' socio-economic characteristics do not significantly influence the choice of agricultural sub-sector engagement.

\section{Theoretical Framework}

Young people are presented with several options daily, from which they must make a choice. Drudgery and the lack of resources such as land, credit facilities, incentives, knowledge, capital, and information are some of the reasons why youth tend to be uninterested in agriculture [42]. The decline in youth participation in primary agricultural production and their preferences for the transformation and service sub-sectors is linked to their perception of the sector's inherent opportunities and challenges. Their decision on sub-sector engagement is therefore influenced by both internal and external factors. These realities of Cameroonian youth are best captured in what has been termed in economics "the Theory of Choice" [43].

\section{Materials and Methods}

\subsection{Sampling Design and Nature of Data}

The study was carried out in the West and South West Regions of Cameroon between August and December 2018. A structured questionnaire was used to obtain cross-sectional data on students' socio-economic characteristics such as age, sex, the current level of education, perceived inherent opportunities, pre-university farming experience, the main occupation of the sponsor/mentor/father, father's level of education, and mother's level of education, among others.

A multistage random sampling technique was used to select university students from the University of Dschang and the University of Buea in the West and South-West Regions of Cameroon, respectively. These two universities were purposefully selected because they both register the highest enrolment in agriculture-related disciplines per year, based on their mixed cultural setting and relatively lower cost of living. These make them convenient destinations for students from across the nation. With the help of admission records for the 2018/2019 academic year from the different faculties, 550 students (275 studying agriculture-related courses and 275 studying non-agricultural coursestechnology, engineering, and biomedical sciences) were randomly selected.

We treat a university as the principal sampling unit and a university major as the secondary sampling unit. According to the registration records, the number of undergraduate students admitted in agriculture and non-agricultural courses (technology and biomedical sciences) in the 2018/2019 academic year in both universities amounted to 1820, comprising 800 at the University of Buea and 1020 at the University of Dschang. Of the 800 undergraduate students in the University of Buea, 215 majored in agriculture-related courses and 585 majored in non-agricultural courses. Similarly, of the 1020 undergraduate students admitted to the University of Dschang, 209 majored in agriculture-related courses and 811 majored in non-agricultural courses.

The number of admitted postgraduate students in the 2018/2019 academic year from both universities was 480, with 216 at the University of Buea and 264 at the University of Dschang. Again, of the 216 postgraduate students at the University of Buea, 110 majored in agriculture-related courses and 106 majored in non-agricultural courses. Of the 264 postgraduate students at the University of Dschang, 128 majored in agriculture-related courses and 136 majored in technology and other professional courses. The Probability 
Proportional to Size (PPS) technique was used to ensure that all levels of education (undergraduate and postgraduate) and all university majors were properly represented in the sample as presented in Table 1. The total sample size of 550 students, therefore, consisted of 275 students majoring in agriculture and 275 students majoring in non-agricultural courses. The survey in 2018 completed interviews of 550 students, with a response rate of about $86 \%$.

Table 1. Sample Distribution in the Study Area.

\begin{tabular}{cccccc}
\hline & \multicolumn{2}{c}{ Agricultural } & \multicolumn{2}{c}{ Non-Agricultural } & \multirow{2}{*}{ Total } \\
\cline { 2 - 5 } & Under-Graduate & Post-Graduate & Under-Graduate & Post-Graduate \\
\hline University of Dschang & 103 & 47 & 109 & 41 & 300 \\
University of Buea & 109 & 16 & 106 & 19 & 250 \\
TOTAL & 212 & 63 & 215 & 60 & 550 \\
\hline
\end{tabular}

\subsection{Empirical Framework}

The strengths, weaknesses, opportunities, and threats (SWOT) analysis has become a fundamental tool for businesses, organizations, and sectors to evaluate their position in the market and is widely used to analyze their internal and external conditions [44]. The four components identify either internal or external considerations. Strengths refer to the internal elements of an organization that facilitate reaching its goals, while weaknesses are those internal elements that interfere with business, organizational, or sectoral success. Opportunities-external aspects that help an organization reach its goals-are not only positive environmental aspects but also opportunities to address gaps and initiate new activities. Threats, on the other hand, are aspects of the organization's external environment that are barriers or potential barriers to reaching its goals [45-48]. The SWOT analysis was used in the study to evaluate students' perceptions of challenges and opportunities within the agricultural sector in Cameroon [49].

The decision of the ith student to choose agriculture or not depends on an unobservable utility index I (also known as latent variables) that is determined by one or more explanatory variables, say student's age $x_{i}$, in such a way that the larger the value of the index $I_{i}$, the greater the probability of student choosing agriculture as a major. The index is expressed in Equation (1) as:

$$
I_{i}=\beta_{1}+\beta_{2} X_{i}
$$

where there is a critical or threshold level of the index, called $I_{i}^{*}$, such that if $I_{i}$ exceeds $I_{i}{ }^{*}$, the student will choose agriculture. Otherwise, he/she will not. The threshold $I_{i}^{*}$, like $I_{i}$, is not observable, but if we assume that it is normally distributed with the same mean and variance, it is possible not only to estimate the parameters of the index given above but also to attain some information about the unobservable index itself. Given the assumption of normality, the probability that $I_{i}^{*}$ is less than or equal to $I_{i}$ can be computed from the standardized normal CDF as:

$$
P_{i}=P(Y=1 \mid X)=P\left(I_{i} * \leq I_{i}\right)=P\left(Z_{i} \leq \beta_{1}+\beta_{2} X_{i}\right)=f\left(\beta_{1}+\beta_{2} X_{i}\right)
$$

where $P(Y=1 / X)$ means the probability that an event occurs given the value(s) of the $X$, and where $Z_{i}$ is the standard normal variable. The probability assumes a value of 1 when the student chooses agriculture and 0 , otherwise.

$X_{i}$ includes socioeconomics characteristics such as age, sex, the current level of education, religious background, location of the childhood home, perceived inherent opportunities, pre-university farming experience, the main occupation of the sponsor/mentor/father, pre-university educational background, pre-university contact with agricultural experts and pre-university academic performance, father's level of education, mother's level of education, student's birth position, and household income.

Among the models used for the dichotomous dependent variable, the Linear Probability Model (LPM) differs from the probit and logit models because it is estimated by 
the ordinary least squares (OLS) technique, which allows for a binary response using regression analysis. Addressing the limitations of the LPM (fitted probabilities that can be less than 0 or greater than 1 and the constant partial effect of explanatory variables) calls for the employment of either the probit or logit model. Probit and logit models are structurally, methodologically, and statistically similar [50]. The former, however, uses the cumulative distribution function (CDF) to explain the behavior of a dichotomous dependent variable, while the latter uses a logistic distribution. The use of either model is thus discretionary given that parameter estimates will likely vary between them because of the varying scales. The binary probit model is most useful in cases where we want to model the event probability for a categorical response variable with two outcomes. The categorization of students into "agricultural" and "non-agricultural" is based on the dichotomous outcome of the decision of enrolment, which characterizes the dependent variable. Because the dependent variable (choice) is binary, the binomial probit model (Equation (2)) was used to determine the factors that influence agricultural and non-agricultural students' choice of agriculture as a major subject in Cameroon.

Similarly, rank-ordered data are often collected in stated preference surveys where respondents are asked to rank hypothetical alternatives (rather than choose a single alternative) to better understand their relative preferences. Despite the widespread interest in collecting data on, and modeling people's preferences for, choice alternatives, rank-ordered data are rarely collected in school enrolment surveys and very little progress has been made in the ability to rigorously model such data and obtain reliable parameter estimates. The ability to estimate rank-ordered probit models offers a pathway for better utilizing rankordered data to understand preferences and recognize that choices may not be absolute in many instances [51]. Given that within any preference category (first, second, or third), each stage chosen is an ordered response; the efficacy of the rank-ordered probit modeling methodology is applied in this study to understand preferences for alternative agricultural sub-sector engagement (Equation (3)). The methodology offers behaviorally intuitive model results with a variety of socio-economic and demographic characteristics, including, age, sex, level of education, religious background, location of a childhood home, passion for a sub-sector, pre-university farming experience, occupation of sponsor/mentor/parents, pre-university educational background, contact with agricultural experts, pre-university academic performance, influencing preference for primary agricultural production, transformation, or related services. The functional form for the chosen pattern in each preference category can be represented as follows:

$$
y_{n}^{*}=\beta^{\prime} x^{n}+\varepsilon_{n}
$$

where $y_{n}^{*}$ is the latent and continuous measure of stage of engagement chosen by student $n, x^{n}$ is a vector of explanatory variables describing the students' socio-demographic characteristics (such as those used in the binomial probit model above), and $\beta^{\prime}$ is the vector of parameters.

The observed discrete stage of engagement $y_{n}$, is determined from the model below,

$$
Y_{n}=\left\{\begin{array}{c}
1 \text { if }-\infty \leq y * \leq \mu 1 \text { (no engagement) } \\
2 \text { if } \mu 1<y * \leq \mu 2 \text { (engagement in primary production) } \\
3 \text { if } \mu 2<y * \leq \mu 3 \text { (engagement in transformation) } \\
4 \text { if } \mu 3<y * \leq \mu 4 \text { (engagement in related services) }
\end{array}\right.
$$

where the $\mu_{i}$ 's are thresholds at different levels to be estimated with $\beta$. Students' ordering choices depend on certain measurable factors, $\mathbf{x}$, and unobservable factors $\varepsilon$. In principle, they could respond to the questionnaire with their $y *$ if asked to do so. They would choose the value that most closely represents their preference. With the normal distribution of error terms, the probability of coded responses varies with the orders given. 
Probability of no engagement $(y=1)$ :

$$
\operatorname{Pr}\left(y_{n}=1\right)=\Phi\left(u_{1}-\beta^{\prime} y_{n}^{*}\right)
$$

Probability of choosing primary agricultural production $(y=2)$ :

$$
\operatorname{Pr}\left(y_{n}=2\right)=\Phi\left(u_{2}-\beta^{\prime} y_{n}^{*}\right)-\Phi\left(u_{1}-\beta^{\prime} y_{n}^{*}\right)
$$

Probability of choosing agricultural transformation $(y=3)$ :

$$
\operatorname{Pr}\left(y_{n}=3\right)=\Phi\left(u_{2}-\beta^{\prime} y_{n}^{*}\right)-\Phi\left(u_{2}-\beta^{\prime} y_{n}^{*}\right)
$$

Probability of choosing agriculture-related services $(y=4)$ :

$$
\operatorname{Pr}\left(y_{n}=4\right)=1-\Phi\left(u_{3}-\beta^{\prime} y_{n}^{*}\right)
$$

in order for all the probabilities to be positive, $0<\mu_{1}<\mu_{2}<\mu_{3}<\mu_{4}$ [52].

Given that a student's perceptions of the inherent opportunities in agriculture and along the agricultural value chain are influenced by several socio-economic characteristics, generating a composite function that captures this perception was necessary. The Principal Component Analysis (PCA) statistical technique was used to generate a latent variable that measures the student's perception of the inherent opportunities in each agricultural sub-sector. This composite variable (perceived inherent opportunities) was generated by pooling together 10 other variables (Attachment to Plants and Animals, Interest in Research, Perceived Employability, Perceived Risk, Required Capital, Perceived Labor Intensiveness, Family's Engagement Sector, Influence of Friends, Perceived Ease of Entry, and Expected Income) and then used as a predictor variable in the rank-ordered probit model.

\subsection{Limitations of the Study}

The scope of this study is limited in terms of the choice of the population, research design, type of data, and instruments for data collection. The population included only university students who were enrolled and majoring in agriculture and technology-related disciplines (undergraduate and postgraduate) in the 2018/2019 academic year. Therefore, the SWOT analysis does not include perceptions and opinions of other stakeholders along Cameroon's agricultural value chain. This may be included in further studies to paint a more holistic perspective of the state of agriculture in Cameroon. With respect to the research design, a cross-sectional survey was used. This design gives a snapshot of the situation under investigation and is time-invariant. Hence, the findings of the study are limited to the perceptions of students undergoing training with no provisions for possible shifts in opinions and perceptions over time. Investigating such changes over time could be an interesting extension of this study. Finally, the main research instrument used in this study is a structured questionnaire which has a weakness in controlling for dishonest responses (especially highly qualitative responses) about opinions and perceptions.

\section{Results}

\subsection{Socio-Economic Characteristics of Students}

Table 2 presents the students' socioeconomic characteristics. The table reveals that student enrolment decreases with an increase in the level of University education (B.Sc., M.Sc., and Ph.D.). As expected, fewer students (7\%) enrolled for doctoral studies than for undergraduate or master's studies ( $78 \%$ or $14 \%$ ). It was also observed that undergraduate students, on average, are younger than postgraduate students. The results further indicate that the proportion of male students at all levels of university education is greater than that of their female counterparts $(63 \%, 52 \%$, and $64 \%$ male representation at the undergraduate, masters, and Ph.D. levels, respectively). This finding may suggest that access to tertiary education in Cameroon is sex-dependent with the male youth having more access than females. Another characteristic that seems to influence students' access to tertiary education 
is their religious background. A majority of students at all levels of university education in Cameroon are Christians $(87 \%, 84 \%$, and $100 \%$ at the undergraduate, master's, and Ph.D. levels, respectively). Although Muslims are generally a minority group in the country, especially in the southern part where the study was conducted, they are even less represented at higher levels of education. The data for this study, therefore, reveal zero representation of Muslims at the Ph.D. level, a 1:5 and 1:8 Muslim to Christian ratio at M.Sc. and undergraduate levels, respectively.

Table 2. Socioeconomic Characteristics of Students.

\begin{tabular}{|c|c|c|c|c|}
\hline \multicolumn{2}{|c|}{ Socioeconomic Characteristics } & \multirow{2}{*}{$\begin{array}{l}\text { BSc } \\
427\end{array}$} & \multirow{2}{*}{$\begin{array}{c}\text { MSc } \\
81\end{array}$} & \multirow{2}{*}{$\begin{array}{c}\text { PhD } \\
42\end{array}$} \\
\hline Sample Size (N) & & & & \\
\hline Variable & $\begin{array}{c}\text { Description of } \\
\text { Response }\end{array}$ & $\begin{array}{c}\text { Frequency } \\
\text { (Percentage) }\end{array}$ & $\begin{array}{c}\text { Frequency } \\
\text { (Percentage) }\end{array}$ & $\begin{array}{c}\text { Frequency } \\
\text { (Percentage) }\end{array}$ \\
\hline \multirow{3}{*}{ Age } & $<20$ & $129(31.9)$ & $16(20.8)$ & $17(43.6)$ \\
\hline & $21-30$ & $273(67.6)$ & $58(75.3)$ & $21(53.8)$ \\
\hline & $>30$ & $2(0.5)$ & $3(3.9)$ & $1(2.6)$ \\
\hline$\%$ of male & Male & $269(63.0)$ & $42(51.9)$ & $27(64.3)$ \\
\hline \multirow{2}{*}{ Discipline of study } & Agriculture & $66(83.5)$ & $66(83.5)$ & $14(33.3)$ \\
\hline & Non-Agriculture & $13(16.5)$ & $13(16.5)$ & $28(66.7)$ \\
\hline \multirow{2}{*}{ Location of the childhood home } & Urban & $367(87.0)$ & $62(78.5)$ & $36(85.7)$ \\
\hline & Rural & $55(13.0)$ & $17(21.5)$ & $6(14.3)$ \\
\hline \multirow{2}{*}{ Pre-university educational background } & Pure Sciences & $271(64.1)$ & $41(51.9)$ & $16(39.0)$ \\
\hline & Others & $152(35.9)$ & $38(48.1)$ & $25(61.0)$ \\
\hline \multirow{2}{*}{ Religious background } & Christian & $375(88.7)$ & $66(83.5)$ & $39(100.0)$ \\
\hline & Others & $48(11.3)$ & $13(16.5)$ & $0(0.0)$ \\
\hline Pre-university farming experience & Yes & $300(71.4)$ & $57(72.2)$ & $31(75.6)$ \\
\hline \multirow{2}{*}{ Occupation of sponsor } & Agriculture & $81(19.6)$ & $19(25.3)$ & $10(25.6)$ \\
\hline & Non-Agriculture & $333(80.4)$ & $56(74.7)$ & $29(74.4)$ \\
\hline Pre-university contact with agric. Expert & Yes & $120(31.7)$ & $21(28.8)$ & $13(36.1)$ \\
\hline \multirow{2}{*}{ Pre-university academic performance } & Average & $256(66.0)$ & $57(86.4)$ & $25(78.1)$ \\
\hline & Excellent & $132(34.0)$ & $9(13.6)$ & $7(21.9)$ \\
\hline \multirow{3}{*}{ Father's level of education } & Primary & $49(13.6)$ & $4(7.5)$ & $3(8.8)$ \\
\hline & Secondary & $116(32.1)$ & $22(41.5)$ & $11(32.4)$ \\
\hline & Tertiary & $196(54.3)$ & $27(50.9)$ & $20(58.8)$ \\
\hline \multirow{3}{*}{ Mother's level of education } & Primary & $97(29.7)$ & $8(17.0)$ & $4(14.3)$ \\
\hline & Secondary & $128(39.1)$ & $21(44.7)$ & $11(39.3)$ \\
\hline & Tertiary & $102(31.2)$ & $18(38.3)$ & $13(46.4)$ \\
\hline \multirow{2}{*}{ Household revenue } & $<150,000$ & $129(42.0)$ & $20(37.0)$ & $8(30.8)$ \\
\hline & $>150,000$ & $178(58.0)$ & $34(63.0)$ & $18(69.2)$ \\
\hline \multirow{2}{*}{ Discipline of study } & Agriculture & $215(51.4)$ & $65(85.5)$ & $14(36.8)$ \\
\hline & Others & $203(48.6)$ & $11(14.5)$ & $24(63.2)$ \\
\hline \multirow{3}{*}{ Primary sub-sector ranking } & $1 \mathrm{st}$ & $96(54.2)$ & $25(43.9)$ & $5(38.5)$ \\
\hline & 2nd & $53(29.9)$ & $16(28.1)$ & $6(46.2)$ \\
\hline & $3 \mathrm{rd}$ & $28(15.8)$ & $16(28.1)$ & $2(15.4)$ \\
\hline \multirow{3}{*}{ Transformation sub-sector ranking } & 1 st & $37(21.5)$ & $9(16.4)$ & $3(23.1)$ \\
\hline & 2nd & $90(52.3)$ & $30(54.5)$ & $5(38.5)$ \\
\hline & $3 r d$ & $45(26.2)$ & $16(29.1)$ & $5(38.5)$ \\
\hline \multirow{3}{*}{ Agri-services Sub-sector Ranking } & $1 \mathrm{st}$ & $42(26.3)$ & $23(41.1)$ & $5(38.5)$ \\
\hline & 2nd & $28(17.5)$ & $9(16.1)$ & $2(15.4)$ \\
\hline & $3 \mathrm{rd}$ & $90(56.3)$ & $24(42.9)$ & $6(46.2)$ \\
\hline
\end{tabular}




\subsection{SWOT Analysis of the Agricultural Sector in Cameroon}

Average student responses about the Strengths, Weaknesses, Opportunities, and Threats of the agricultural sector in Cameroon were synthesized and summarized in Figure 1.

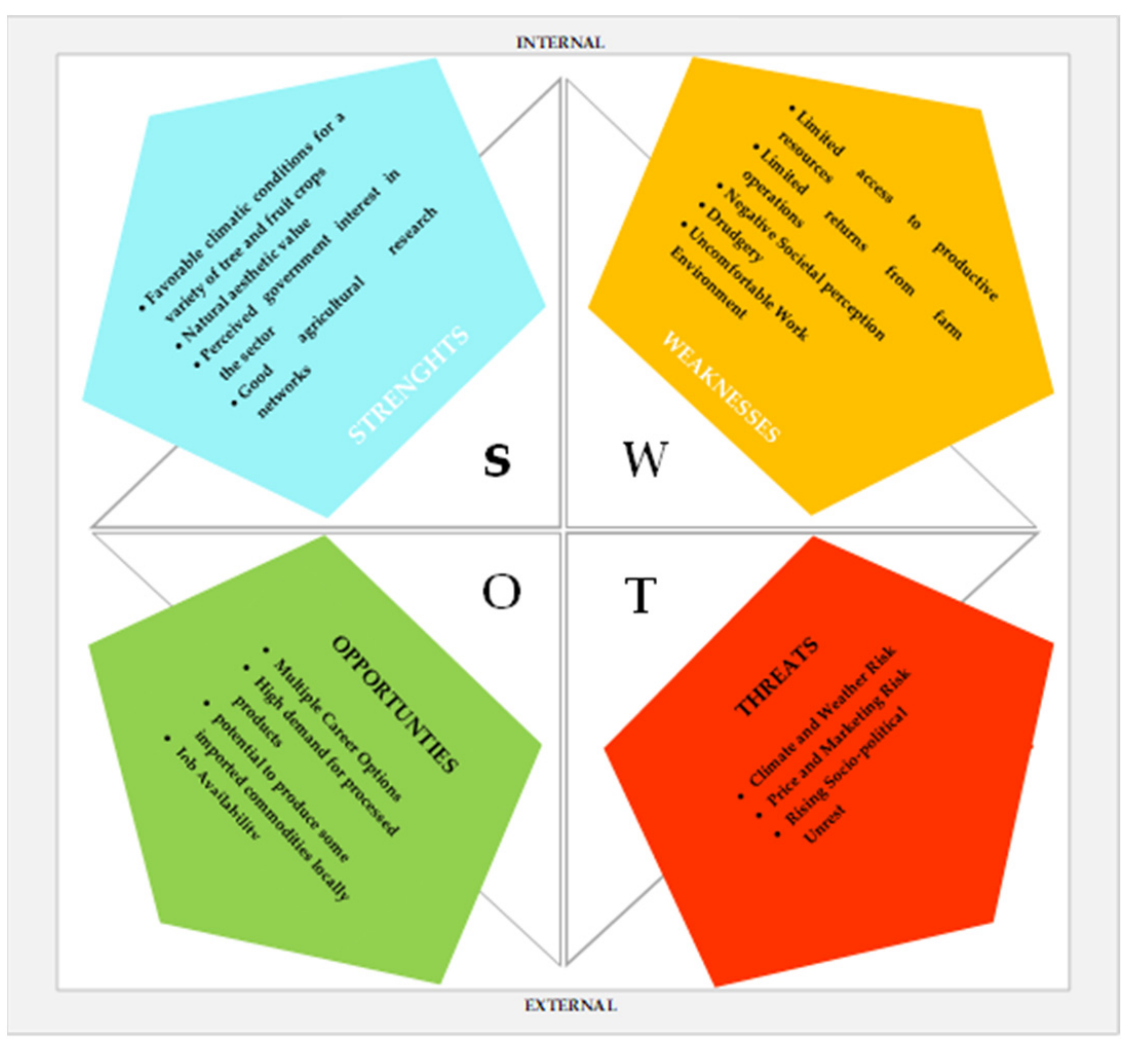

Figure 1. SWOT Analysis of Cameroon's Agricultural Sector.

\subsubsection{Strengths of the Agricultural Sector in Cameroon}

These are classified in terms of the natural and institutional.

\section{(1) Natural}

Cameroon offers a wide range of tropical climates with highly contrasting physical features which favour the cultivation of a variety of tree and fruit crops as well as the rearing of diverse animals. In addition, the natural beauty of agricultural scenery is aesthetically pleasing and evokes delightful emotional responses.

\section{(2) Institutional}

Perceived government interest in the sector appears as the top-ranking strength of the agricultural sector in Cameroon. Government interest in the sector is evident in its "Growth and Employment Strategy" which identifies agriculture as the engine for economic growth and job creation. It recognizes the need for agricultural diversification, increased productivity, and large-scale investments in the sector [53].

Furthermore, there exists a well-developed agricultural research network in Cameroon with the Institute of Agricultural Research for Development (IRAD) as the principal research agency. IRAD provides training, improved varieties of inputs, technology, and support which boosts operations in the sector. Its activities are complementary to those of other public research institutes such as the Biotechnology Centre of Nkolbisson, the Crop Production Department in the Faculty of Agronomy and Agricultural Sciences (FASA) of the Université de Dschang, the Faculty of Agriculture and Veterinary Medicine of the University of Buea, the African Research Center on the Banana tree and the Plantain in Njombé, and the Biotechnology Laboratory of the Regional Centre of Agricultural Research for Development of Ekona. Private institutes involved in agricultural research include 
the Cameroon Development Corporation (CDC) — an agro-industrial complex that grows, processes, and markets tropical export crops, MAÏSCAM, the Northwest Development Mission, SODECOTON, and SOCAPALM.

\subsubsection{Weaknesses of the Agricultural Sector in Cameroon}

Weaknesses are grouped into the following categories: access to productive resources, marketing, public perception, and business/work environment.

\section{(1) Access to productive resources}

The majority of students are willing to engage in agriculture, but access to the resources (land, credits, improved technologies, and practical skills) required for successful agribusiness ventures is a major challenge. Access to land is fundamental to starting a farm and securing it is more often than not very difficult, especially for female youths. Similarly, most financial service providers are reluctant to provide their services (credit, savings, and insurance) to youth. This is because (among other reasons) a majority of youth are not financially empowered/literate, often lacking the required collateral. The unavailability of agricultural insurance services further constrains the activities of youths.

\section{(2) Marketing}

Given that food crops are highly perishable, returns on farming operations tend to be small due to post-harvest losses, limited transformation, little or no opportunities for e-commerce, and an underdeveloped marketing channel. Furthermore, weak pricing mechanisms, limited market information, and poor communication make the sector non-lucrative.

\section{(3) Public perception}

According to Majid [54], an individual's perceptions and choices towards a particular career may depend on their cultural/societal ideals. In Cameroon, farming is regarded by society as a lowly, back-breaking, unglamorous, dirty job needing little skills. Farming is rarely portrayed in the media as a young person's game and can be seen as old-fashioned, unprofitable, and hard work. There is usually little pride and dignity associated with it and it is generally unattractive. Youths tend to prefer white-collar jobs over farming since it is characterized by little or no mechanization. Worse still, agricultural courses are regarded to be a reserve course for the less intelligent and less privileged.

\section{(4) Business/work environment}

With regards to starting a business, Cameroon is ranked 104 out of 190 economies with a score of 86.3 on 100. On average, it takes about 13.5 days to register a business in Cameroon [55], a condition that discourages and scares many. Also, the drudgery nature of most farm operations is unattractive, particularly to the youth. Besides, youth working in agriculture mainly operate in small, unincorporated family businesses as self-employees or as contributing family workers with very little or no pay-often having very little assurance that they will be able to work in their job as long as they please (lack of job stability). Expected uncompetitive wages and high physical demands, therefore, cause them to shy away from the sector [25]. Besides, farmers live in rural areas where hospitals, markets, and other facilities are often miles away from the farm-a situation that makes living and working on the farm risky and uncomfortable.

\subsubsection{Opportunities in the Agricultural Sector in Cameroon}

These are grouped into the following categories: multiple productive career options and un(under)-exploited nodes on the value chain.

(1) Multiple career options

The agricultural value chain offers a variety of opportunities with career options that go beyond farming and ranching to include transformation, research, and other related services. Students perceive this as a unique sector advantage that should be explored. 


\section{(2) Un(under)-exploited nodes on the value chain}

The agricultural transformation sub-sector in Cameroon appears to be unexploited. The scarcity of processed/packaged cooking ingredients and meals, dairy products, snacks, and staple foods recorded in recent years is a pointer to this. The main factors pushing growth in demand for packaged food remain the country's rising population and internal migration, specifically away from regional settlements and rural areas towards the major urban areas of Yaoundé and Douala. Besides, there are very few local players in the packaged food sector besides Nestlé, which is the leading player in Cameroon. More so, Cameroon still imports commodities such as rice, corn, and fish despite its significant market share for these products and its potential to produce them locally.

\subsubsection{Threats of the Agricultural Sector in Cameroon}

These are grouped into the following categories: wide-ranging risks and rising sociopolitical unrest.

\section{(1) Wide-ranging risks}

The agricultural sector in Cameroon is subject to risks ranging from climate/weather to market and injury risks, among others. The risks associated with the increasing natural variability of rainfall and temperatures pose serious challenges to agricultural production and food security. Market risks in the form of uncertainty concerning prices, costs, and market access equally loom over the sector. Volatility in agricultural commodity prices is often caused by weather shocks and their effects on yields, energy price shocks, and asymmetric access to information. In addition, safe execution of tasks requires sufficient working ability with the demands of the work. Hazards related to the work environment caused by injury risk factors such as machinery, animals, and working surfaces (leading to slips, trips, and falls) scare youth from engaging in agricultural activities at all levels.

(2) Rising socio-political unrest

Cameroon is facing multiple complex emergencies, mainly in the Far North region due to the Boko Haram insurgency, the crisis in the two anglophone regions (North-West and South-West) as well as the crisis linked to incoming refugees from the Central African Republic in the eastern regions. All three are marked by armed conflict, significantly affecting the population and intensifying their vulnerabilities [56]. The economic fallout from this rising political instability is a major threat to agricultural sector activities as it has the potential to significantly suppress value chain activities.

\subsection{Maximum Likelihood Estimates of the Determinants of Choice of Agriculture as a University Major}

Table 3 presents the factors that influence the choice of agriculture as a university major by students in Cameroon. It shows that the choice is significantly influenced by the student's: sex, pre-university farming experience, pre-university academic background, pre-university academic performance, mother's level of education, and household income.

Compared to female students, male students have a significantly greater probability of choosing agriculture as a university major. Similarly, relative to students without any preuniversity farming experience, the probability of choosing agriculture as a university major is significantly lower by $0.235(p>0.05)$ for students with pre-university farming experience. In other words, students with pre-university farming experience are less likely to choose agriculture as a major when compared to those without farming experience. Judged against students with a non-science pre-university academic background, the probability of taking up agriculture as a major is significantly higher by 0.160 for students with a pre-university academic background in pure sciences. Also, compared to students with an average pre-university academic performance, the probability of taking up agriculture as a major for students with excellent performance is less by 0.170 . Furthermore, as opposed to students whose mothers' level of education is the primary, the probability of taking up agriculture as a major for students whose mothers are at the secondary education level is 
significantly greater by 0.230 . On the contrary, the probability of taking up agriculture as a major for students whose mothers have acquired tertiary education is less by 0.090 . Hence, an increase in mother's level of education from primary to secondary increases students' chance of taking up agriculture as a major and tertiary, while a further increase from secondary to tertiary reduces students' chances of taking up agriculture as a major. Finally, when compared with students from households with monthly income below the average (\$272 US; as estimated from field survey), the probability of taking up agriculture as a major for students from a household with monthly income above the average is significantly greater by 0.170 .

Table 3. Maximum Likelihood Estimates of the Determinants of Choice of Agriculture as a University Major.

\begin{tabular}{|c|c|c|}
\hline Variable & Coefficient & $\begin{array}{c}\text { Marginal } \\
\text { Effect (dy/dx) }\end{array}$ \\
\hline Student's Age (in years) & 0.062 & $0.019 *(0.011)$ \\
\hline $\begin{array}{c}\text { Student's Sex } \\
\text { (1 if male, } 0 \text { otherwise) }\end{array}$ & 0.830 & $0.252^{* * *}(0.06)$ \\
\hline \multicolumn{3}{|l|}{ The current level of study } \\
\hline The current level of study is masters ( 1 if yes, 0 otherwise) & -0.028 & $-0.008(0.135)$ \\
\hline The current level of study is Doctoral ( 1 if yes, 0 otherwise) & 0 & \\
\hline Religious background ( 1 if Christian, 0 otherwise) & 0.519 & $0.157(0.118)$ \\
\hline $\begin{array}{l}\text { Location of the childhood home } \\
\text { (1if Rural areas, } 0 \text { otherwise) }\end{array}$ & -0.029 & $-0.009(0.081)$ \\
\hline $\begin{array}{l}\text { Perceived level of inherent opportunities in agriculture } \\
\qquad(1 \text { if High, } 0 \text { otherwise) }\end{array}$ & -0.333 & $-0.101(0.069)$ \\
\hline $\begin{array}{l}\text { Pre-university farming experience } \\
\text { ( } 1 \text { if yes, } 0 \text { otherwise })\end{array}$ & -0.750 & $-0.227^{* * *}(0.076)$ \\
\hline Main occupation of father ( 1 if agriculture-related, 0 otherwise) & 0.187 & $0.057(0.081)$ \\
\hline $\begin{array}{l}\text { Pre-university educational background of the student } \\
\text { ( } 1 \text { if pure sciencies, } 0 \text { otherwisse })\end{array}$ & 0.519 & $0.157^{* *}(0.071)$ \\
\hline $\begin{array}{l}\text { Pre-university contact of the student with agricultural experts } \\
\text { ( } 1 \text { if yes, } 0 \text { otherwise) }\end{array}$ & -0.314 & $-0.095(0.068)$ \\
\hline Pre-university academic performance (1 if excellent, 0 otherwise) & -0.574 & $-0.174(0.062)$ \\
\hline \multicolumn{3}{|l|}{ Father's level of education } \\
\hline Secondary ( 1 if yes, 0 otherwise) & -0.342 & $-0.100(0.106)$ \\
\hline Tertiary ( 1 if yes, 0 otherwise) & -0.302 & $-0.089(0.108)$ \\
\hline \multicolumn{3}{|l|}{ Mother's level of Education } \\
\hline Secondary ( 1 if yes, 0 otherwise) & 0.768 & $0.229 * * *(0.085)$ \\
\hline Tertiary ( 1 if yes, 0 otherwise) & -0.272 & $-0.089(0.102)$ \\
\hline Student's birth position in th house (1st, 2nd, 3rd) & 0.093 & $0.028(0.017)$ \\
\hline Household income (in US\$) $(<272,>272)$ & 0.554 & $0.168^{* *}(0.069)$ \\
\hline Constant & -1.911 & \\
\hline Number of observations & 196 & \\
\hline LR chi2(17) & $54.89 * * *$ & \\
\hline Prob > chi2 & 0.0000 & \\
\hline
\end{tabular}

\footnotetext{
${ }^{*}$ Significant at $10 \%,{ }^{* *}$ Significant at $5 \%$, and ${ }^{* * *}$ Significant at $1 \%$, respectively. Note: The figures in parentheses represent the standard errors
} 


\subsection{Maximum Likelihood Estimates of the Determinants of Students' Preferences of Agricultural Sub-Sector Engagement}

Table 4 presents the factors that influence the preferences for agricultural sub-sectors by university students in Cameroon. It shows that preference is significantly determined by the student's level of study and the location of the childhood home.

Table 4. Maximum Likelihood Estimates of the Determinants of Students' Preferences of Agricultural Sub-sector Engagement.

\begin{tabular}{|c|c|c|}
\hline Rank & Variables & Coefficient (Std. Err.) \\
\hline \multicolumn{3}{|l|}{1} \\
\hline \multirow{16}{*}{2} & Student's Age (in years) & $0.017(0.041)$ \\
\hline & Student's Sex & $-0.534(0.478)$ \\
\hline & The current level of study & \\
\hline & The current level of study is masters ( 1 if yes, 0 otherwise) & $-1.655^{* *}(0.760)$ \\
\hline & The current level of study is doctoral ( 1 if yes, 0 otherwise) & $0.379(1.054)$ \\
\hline & Religious background ( 1 if Christian, 0 otherwise) & $-0.502 *(0.345)$ \\
\hline & Location of the childhood home (1if Rural area, 0 otherwise) & $1.230 * *(0.684)$ \\
\hline & Pre-university farming experience ( 1 if yes, 0 otherwise) & $-0.037 *(0.562)$ \\
\hline & Perceived level of inherent opportunities in agriculture ( 1 if High, 0 otherwise) & $0.241(0.166)$ \\
\hline & Pre-university educational background of the student ( 1 if pure sciences, 0 otherwise) & $-0.650(0.589)$ \\
\hline & Pre-university contact of the student with agricultural experts ( 1 if yes, 0 otherwise & $1.218(0.464)$ \\
\hline & Pre-university academic performance ( 1 if excellent, 0 otherwise) & $-0.607(0.521)$ \\
\hline & Father's level of education & $0.446(0.367)$ \\
\hline & Mother's level of education & $-0.316(0.372)$ \\
\hline & Household income (in US\$) $(<272,>272)$ & $0.293(0.504)$ \\
\hline & Constant & $1.777(1.563)$ \\
\hline \multirow{18}{*}{3} & Student's Age (in years) & $0.096(0.092)$ \\
\hline & Student's Sex & $0.977(1.091)$ \\
\hline & The current level of study & \\
\hline & The current level of study is masters ( 1 if yes, 0 otherwise) & $-4.077(1.852)$ \\
\hline & The current level of study is doctoral ( 1 if yes, 0 otherwise) & \\
\hline & Religious background ( 1 if Christian, 0 otherwise) & $-1.557(0.833)$ \\
\hline & Location of the childhood home (1if Rural area, 0 otherwise) & $3.299(1.584)$ \\
\hline & Pre-university farming experience ( 1 if yes, 0 otherwise) & $-2.455(1.378)$ \\
\hline & Perceived level of inherent opportunities in agriculture( 1 if High, 0 otherwise) & $0.391(0.351)$ \\
\hline & Pre-university educational background of the student ( 1 if pure sciences, 0 otherwise) & $-0.778(1.215)$ \\
\hline & Pre-university contact of the student with agricultural experts ( 1 if yes, 0 otherwise & $0.209(0.963)$ \\
\hline & Pre-university academic performance ( 1 if excellent, 0 otherwise) & $-0.205(1.065)$ \\
\hline & Father's level of education & $0.726(0.761)$ \\
\hline & Mother's level of education & $-0.135(0.792)$ \\
\hline & Household income (in US\$) $(<272,>272)$ & $0.357(1.063)$ \\
\hline & Constant & $3.319(3.612)$ \\
\hline & Number of observations & 255 \\
\hline & Wald chi2(28) & 20.08 \\
\hline
\end{tabular}

${ }^{*}$ Significant at $10 \%$ and ${ }^{* *}$ Significant at $5 \%$ respectively. Note: The figures in parenthesis represent the standard errors

\subsubsection{Primary versus Secondary Sector Comparison}

Results show that the probability that older students would engage in the agricultural transformation sub-sector is 0.017 times greater than their probability of engaging in primary production. This statistic is not significant, however $(p>0.05)$. Likewise, the coefficient of sex indicates that male students have a 0.534 lower likelihood of engaging in agricultural transformation compared to primary production. Besides, students at the MSc level have a significantly lower likelihood of engaging in agricultural transformation compared to primary production (1.660). Ph.D. students, on the other hand, have a 0.379 greater likelihood of choosing transformation over primary production. Christians equally have a 0.502 lower chance of engaging in transformation over primary production. The location of childhood home also affects the preference of sector engagement. Students 
who spent a majority of their childhood in rural areas have a significantly greater likelihood of engaging in agricultural transformation over primary production (1.231). By the same token, students who had the pre-university farming experience have a 0.037 lower likelihood of engaging in agricultural transformation over primary production. More so, students who perceived opportunities in agriculture as high have a 0.241 greater likelihood of engaging in agricultural transformation than in primary production. Also, students with a pre-university educational background in pure sciences have a 0.650 lower likelihood of engaging in transformation than in primary production. Similarly, students who had some form of contact with an agricultural expert before university have a 1.218 greater likelihood of engaging in transformation than in primary production. Also, students who had an excellent pre-university academic performance are 0.607 times less likely to engage in transformation than in primary production. Also, students with highly educated fathers have a 0.446 greater likelihood of taking up transformation than primary production whereas students with highly educated mothers have a 0.316 lower likelihood of taking up transformation over primary production. Finally, students from wealthier homes have a 0.293 greater likelihood of taking up transformation over primary production.

\subsubsection{Primary versus Tertiary Sector Comparison}

Our findings reveal that older students have a 0.096 greater likelihood of engaging in agriculture-related services than in primary production-a result that was not significant, however $(p>0.05)$. Also, male students have a 0.970 greater likelihood of engaging in agriculture-related services than in primary production. This result was, again, not significant. Similarly, MSc students have a 4.077 lower likelihood of engaging in agriculture-related services than primary production. Ph.D. candidates, on their part, are 0.160 times more likely to engage in agriculture-related services than in primary production. Again, students with a Christian background have a 1.55 lower likelihood of engaging in agriculture-related services than in primary production. Students who grew up in rural areas have a 3.299 greater likelihood of engaging in agriculture-related services than in primary production. Students who had some pre-university farming experience have a 2.455 lower likelihood of engaging in agriculture-related services than in primary production. Also, students who perceive greater inherent opportunities in agriculture have a 0.391 greater likelihood of engaging in agriculture-related services than in primary production. Also, Students with a pre-university educational background in pure sciences have a 0.778 lower likelihood of engaging in agriculture-related services than in primary production. Besides, students who have had some form of contact with agricultural experts have a 0.209 greater likelihood of engaging in agriculture-related services than in primary production. Besides, students with an excellent pre-university academic performance have a 0.205 lower likelihood of engaging in agriculture-related services than in primary production. Similarly, students with highly educated fathers have a 0.726 greater likelihood of engaging in agriculture-related services than in primary production. On the other hand, students with highly educated mothers have a 0.133 lower likelihood of engaging in agriculture-related services than in primary production. This result was, again, not significant. Finally, these results indicate that students from wealthier homes have a 0.37 greater likelihood of engaging in agriculture-related services than in primary production. This result was, again, not significant.

\section{Discussion}

\subsection{Determinants of Choice of Agriculture as a University Major}

Although the choice of agriculture as a university major is a function of many factors, only the student's sex, pre-university farming experience, educational background, mother's level of income, and household income were seen to be significant determinants of this choice.

Access to, and control over, assets (especially land) could explain why male students are more likely to choose agriculture as a university major than their female counterparts. 
Land is the most important physical asset for production and income generation for a vast majority of rural communities. While youth may not yet own land-due to the "restrictive" customary land tenure system in Cameroon [57], their expectations of inheritance differ by gender [58]. In addition, Cameroon's inheritance system is predominantly patrilineal. A greater proportion of young men, therefore, expect to inherit land than young women and this most likely justifies their significantly higher likelihood of choosing agriculture. This agrees closely with the findings of IFPRI in 2016 [59].

In addition, students with pre-university farming experience will be more aware of the weaknesses and threats within the sector and this could explain their lower tendency to choose agriculture as a university major. Sector weaknesses (limited access to productive resources, limited returns from farm operations, and negative societal perception of farming, drudgery, and uncomfortable work/business environment) and threats (climate/weather risks, price and marketing risks, and rising sociopolitical unrest) are a serious demotivation to these aspiring youth. Besides, hatred for agriculture is developed while in secondary school where wrongdoers are often punished by being made to manually till, make ridges, and sow on school farms. As a result, students associate agriculture with drudgery and develop a negative perception of agriculture both as a university major and as a career option. These findings are similar to the results obtained by Jones \& Larke [60] as well as Amegnaglo et al. [61], who both show that the probability for graduate students to participate in the agricultural value chain decreases as students gain farming experience. Improving the attractiveness and working conditions in the agricultural sector could be a strategy to increase students' likelihood of taking up agriculture as a university major and hence participating in agriculture. These results, however, contradict later findings by Etim \& Udoh [62] who recorded that youths with more years of farming experience are more willing to participate in new agricultural activities than those with less. Fizer [63], on his part, argues that there is no significant relationship between growing up on a farm and choosing agriculture as a university major.

Likewise, the finding that students with a pre-university background in pure sciences are more likely to choose agriculture as a university major ties with a priori expectations. This is because a pass in some science subjects such as mathematics, chemistry, physics, and biology is usually a requirement for admission into most agricultural colleges and faculties in Cameroon. Pre-university exposure to pure sciences can therefore be a tool to improve university enrolment in agriculture-related disciplines.

Also, an increase in the mother's level of education may be associated with a greater awareness of the strengths and opportunities in the agricultural sector. This tendency, coupled with the common observation that mothers generally have a great influence over their children's career choices, may increase students' odds of choosing agriculture as a major. This agrees with the findings of Baliyan and Nenty [64], who found that an increase in the mother's level of education significantly increases a student's likelihood of accepting agriculture. It is proffered that there is a need to build and implement effective policies to improve levels of education for female children to the secondary level.

Furthermore, the finding that students from homes with higher monthly incomes are more likely to take agriculture as a university major agrees with those of Baliyan and Nenty [64], which showed an increase in family income significantly increases a student's likelihood to accept agriculture. This may be a result of the relative ease/security these students may have in securing the financial capital usually required to start an agribusiness venture. This reinforces the need for policy measures that could increase household income in Cameroon, as this could lift families out of poverty and offer them more opportunities.

Though insignificant in influencing students' choice of agriculture as a university major, socioeconomic characteristics such as age, sex, pre-university contact with agricultural experts, and religious background can be used as control variables in the formulation and implementation of policies about youth involvement in agribusiness and rural economic activities. 


\subsection{Determinants of Preferences of Agricultural Sub-Sector Engagement}

While preference for sub-sector engagement is a function of many factors, only student's level of study, contact with agricultural experts, and location of childhood home were seen to be significant determinants of preference.

As students further their education, they tend to engage at higher levels on the agricultural value chain. Such students prioritize off-farm agriculture-related services such as teaching, research, and extension. This is probably because these services appear to be more lucrative, often requiring young people with innovative, institutional, and financial system knowledge and other qualities that illiterate farmers are not likely to have. This finding corroborates that of Mwaura [65] in their examination of neoliberal subjectivities and agricultural livelihoods among educated youth in Kenya. By implication, policies that regulate levels of education can be used to allocate human resources into different agricultural sub-sectors, subject to felt needs.

The tendency of students from rural areas to prefer agricultural transformation and services over primary production can be associated with the drudgery of primary production which they might have observed or experienced. These findings are largely in agreement with the findings of Aphunu and Atoma [66] that young people from Delta Central Agricultural Zone of Delta State who have ties with rural areas are more able to embrace professional and technical work in agriculture. Improving the attractiveness of the primary production sub-sector, in particular, could offer a veritable means to revamp declining youth interest in primary production. Greater use of ICT could play a great role in inspiring and attracting more youths into the sub-sector [1,67-69]. Not only can ICT be used to educate and train those unable to attend higher education institutions, but it can be used as a tool to help young farmers spread knowledge and experiences, build networks, and find employment. The media, ICT, and social media can all be used to help better agriculture's image across a broad audience.

Although insignificant in influencing students' preferences for the agricultural sector of engagement, socioeconomic characteristics like age and household income can still be used as control variables in policymaking.

\section{Conclusions}

Youth represent a high proportion of the population in Cameroon. They can play a major role as drivers of change in addressing the country's challenges related to food security, commercial dependence on imports, employment, etc. A better understanding of what motivates youths and what guides their choices and preferences to engage in education related to the agricultural sector is very important. We draw from the analysis four major points for consideration.

Students are conscious and rational in taking decisions about their educational and career choices. Their perception of inherent strengths, weaknesses, opportunities, and threats informs their educational/career choices.

The study highlighted the key determinants of students' choices of agriculture as a university major such as sex, pre-university farming experience, pre-university academic background, mother's level of education, and household income. Therefore, it is recommended that the above determinants should be prioritized in crafting policies to encourage youth involvement in agribusiness and rural economic activities. Improving the attractiveness of especially the primary subsector could enhance youth attraction to the sector. This will in turn ramp up agricultural production, processing, and trade within Cameroon and beyond.

The primary production, transformation, and agriculture-related services sub-sectors are equally important in ensuring a balanced agricultural sector development. There is, therefore, the need for government and other stakeholders to modernize primary agricultural production and transformation in synergy with a vibrant agriculture-related services sub-sector. Ensuring the effective participation of youths along all nodes of the agricultural value chain is as urgent as it is requisite, and agriculture that will attract 
young people must be dynamic, competitive, and profitable. The limits of the study were identified to inform future research in terms of the choice of the population, research design, type of data, and instruments for data collection.

Author Contributions: Conceptualization, C.J.M.; Data curation, P.M.D.-N.; Formal analysis, C.J.M.; Funding acquisition, Z.B.; Investigation, C.J.M., and G.S.; Methodology, C.J.M.; Project administration, Z.B.; Resources, V.M.; Supervision, T.A. and P.M.D.-N.; Validation, T.A. and P.M.D.-N.; Visualization, T.A. and P.M.D.-N.; Writing—original draft, C.J.M.; Writing—review \& editing, T.A., P.M.D.-N., and V.M. All authors have read and agreed to the published version of the manuscript.

Funding: This research was funded by the International Fund for Agricultural Development (IFAD) under the grant 2000001374 "Enhancing Capacity to Apply Research Evidence (CARE) in Policy for Youth Engagement in Agribusiness and Rural Economic Activities in Africa" Project in the International Institute of Tropical Agriculture (IITA).

Institutional Review Board Statement: Not applicable.

Informed Consent Statement: Not applicable.

Data Availability Statement: Not applicable.

Acknowledgments: The authors are thankful to the students of the two universities (the University of Buea and the University of Dschang) who graciously completed the structured questionnaire of the survey that was used to obtain cross-sectional data. The authors also thank the four anonymous reviewers whose comments have contributed positively to the quality of this paper.

Conflicts of Interest: The authors declare no conflict of interest. The funders had no role in the design of the study; in the collection, analyses, or interpretation of data; in the writing of the manuscript, or in the decision to publish the results.

\section{References}

1. FAO. Youth Employment in Agriculture as a Solid Solution to Ending Hunger and Poverty in Africa: Engaging through Information and Communication Technologies (ICTs) and Entrepreneurship; FAO: Rome, Italy, 2018.

2. Adekunle, A.A.; Ellis-Jones, J.; Ajibefun, I.; Nyikal, R.A.; Bangali, S.; Fatunbi, A.O.; Ange, A. Agricultural Innovation in SubSaharan Africa: Experiences from Multiple Stakeholder Approaches. Forum for Agricultural Research in Africa; FARA: Accra, Ghana, 2012; Available online: https:/ / www.researchgate.net/publication/259998980_Agricultural_Innovation_in_Sub-Saharan_Africa_ experiences_from_multiple-stakeholder_approaches (accessed on 28 May 2021).

3. Kumeh, E.M.; Omulo, G. Youth's access to agricultural land in Sub-Saharan Africa: A missing link in the global land grabbing discourse. Land Use Policy 2019, 89, 104210. [CrossRef]

4. Morokong, T.; Pienaar, L. A Macro-Economic Report on the Africa Agenda: Western Cape Agriculture; ResearchGate: Berlin, Germany, 2019. [CrossRef]

5. Thurlow, J.; Dorosh, P.; Davis, B. Demographic change, agriculture, and rural poverty. Sustain. Food Agric. 2019, 31-53. [CrossRef]

6. Sanging, N.; Lohento, K. Youth in Agribusiness within an African Agricultural Transformation Agenda; AFDB: Abidjan, Côte d'Ivoire, 2015.

7. FAO. Public-Private Partnerships for Agribusiness Development-A Review of International Experiences; FAO: Rome, Italy, 2016.

8. Njeru, L.K. Youth in agriculture: Perception and challenges of enhanced participation in Kajiodo North Sub County, Kenya. Greener J. Agric. Sci. 2017, 7, 203-209. [CrossRef]

9. Magagula, B.; Tsvakirai, C.Z. Youth perceptions of agriculture: Influence of cognitive processes on participation in agripreneurship. Dev. Pract. 2020, 30, 234-243. [CrossRef]

10. Schmidt, E.; Woldeyes, F.B. Rural youth, and employment in Ethiopia. In Youth and Jobs in Rural Africa; Oxford University Press: Oxford, UK, 2019; pp. 109-136.

11. FAO; IFAD. Youth and Agriculture: Key Challenges and Concrete Solutions; FAO, CTA, IFAD: Rome, Italy, 2014.

12. Bank, W. Cameroon Agriculture Sheet. World Development Indicators; The World Bank: Washington, DC, USA, 2014. Available online: https://cameroon.opendataforafrica.org/hxycnxc/cameroon-agriculture-sheet (accessed on 27 May 2021).

13. Braimoh, A. Building Resilient Food Systems in Africa. One Earth 2020, 3, 282-284. [CrossRef]

14. Ighobor, K. Africa's Jobless Youth Cast a Shadow over Economic Growth; Special Edition on Youth 2017; Africal Renewal: New York, NY, USA, 2017.

15. African Development Bank Group. Jobs for Youth in Africa: Strategy for Creating 25 Million Jobs and Equipping 50 Million Youth 2016-2025.2016. Available online: https:/ /www.afdb.org/fileadmin/uploads/afdb/Documents/Boards-Documents/ Bank_Group_Strategy_for_Jobs_for_Youth_in_Africa_2016-2025_Rev_2.pdf (accessed on 27 May 2021).

16. FAO. FAO Promoting Decent Employment Opportunities for Rural Youth; FAO: Rome, Italy, 2013. 
17. ILO. Global Employment Trends for Youth 2020: Technology and the Future of Jobs; ILO: Geneva, Switzerland, 2020.

18. Stacie Irwin, P.M. Justin Flynn How Youth-Specific Is Africa's Youth Employment Challenge? K4D Emerging Issues Report: Brighton, $\mathrm{UK}, 2018$.

19. Ayanda, I.F.; Olooto, F.; Motunrayo, A.; Abolaji, G.T.; Yusuf, O.J.; Subair, S.K. Perception of Kwara state university agricultural students on farming as means of a future livelihood. Int. J. AgriScience 2012, 2, 1053-1061.

20. Daum, T.; Birner, R. The neglected governance challenges of agricultural mechanization in Africa-insights from Ghana. Food Security 2017, 9, 959-979. [CrossRef]

21. Sumberg, J.; Okali, C. Young People, Agriculture, and Transformation in Rural Africa: An “Opportunity Space” Approach. Innov. Technol. Gov. Glob. 2013, 8, 259-269. [CrossRef]

22. Tadele, G.; Gella, A.A. 'A Last Resort and Often Not an Option at All': Farming and Young People in Ethiopia. IDS Bull. 2012, 43, 33-43. [CrossRef]

23. Bezu, S.; Holden, S. Are Rural Youth in Ethiopia Abandoning Agriculture? World Dev. 2014, 64, 259-272. [CrossRef]

24. Metelerkamp, L.; Drimie, S.; Biggs, R.J.A. We're ready, the system's not-youth perspectives on agricultural careers in South Africa. Agrekon 2019, 58, 154-179. [CrossRef]

25. Mibey, M.C. Factors Influencing Youth Involvement in Agribusiness Projects in Bomet Central Sub-County, Kenya. Ph.D. Thesis, University of Nairobi, Nairobi, Kenya, 2015.

26. Obayelu, O.A.; Fadele, I.O. Choosing a career path in Agriculture: A tough calling for youths in Ibadan metropolis, Nigeria. Agric. Trop. Et Subtrop. 2019, 52, 27-37. [CrossRef]

27. White, B. Agriculture and the Generation Problem: Rural Youth, Employment and the Future of Farming. IDS Bull. 2012, 43, 9-19. [CrossRef]

28. Swarts, M.B.; Aliber, M. The 'youth, and agriculture' problem: Implications for rangeland development. Afr. J. Range Forage Sci. 2013, 30, 23-27. [CrossRef]

29. Anyidoho, N.A.; Leavy, J.; Asenso-Okyere, K. Perceptions, and Aspirations: A Case Study of Young People in Ghana's Cocoa Sector. IDS Bull. 2012, 43, 20-32. [CrossRef]

30. Moitui, J. Challenges and Opportunities in Agriculture for African Youth; CTA: Wageningen, The Netherlands, 2019.

31. EPRC. Youth Engagement in Agriculture in Uganda: Challenges and Prospects; EPRC: Kampala, Uganda, 2013.

32. Agricultures, F. Future Farmers? Exploring Youth Aspirations for African Agriculture; The University of Sussex: Brighton, UK, 2010.

33. Njeru, L.; Karega, L. Youth in Agriculture; Perceptions and Challenges for Enhanced Participation in Kajiado North Sub-County, Kenya Youth in Agriculture; Perceptions and Challenges for Enhanced Participation in Kajiado North Sub-County, Kenya. Greener J. Agric. Sci. 2017, 7, 203-209. [CrossRef]

34. Leavy, J.; Smith, S.J.F.A.D.P. Future farmers: Youth aspirations, expectations and life choices. Future Agric. 2010, $13,1-15$.

35. Amare, M.; Abay, K.A.; Arndt, C.; Shiferaw, B.J.P.; Review, D. Youth Migration Decisions in Sub-Saharan Africa: Satellite-Based Empirical Evidence from Nigeria. Popul. Dev. Rev. 2021, 47, 151-179. [CrossRef]

36. Myeni, L.; Moeletsi, M.; Thavhana, M.; Randela, M.; Mokoena, L. Barriers affecting sustainable agricultural productivity of smallholder farmers in the eastern free state of South Africa. Sustainability 2019, 11, 3003. [CrossRef]

37. Yami, M.; Feleke, S.; Abdoulaye, T.; Alene, A.D.; Bamba, Z.; Manyong, V. African rural youth engagement in agribusiness: Achievements, limitations, and lessons. Sustainability 2019, 11, 185. [CrossRef]

38. Ripoll, S.; Andersson, J.; Badstue, L.; Büttner, M.; Chamberlin, J.; Erenstein, O.; Sumberg, J. Rural transformation, cereals and youth in Africa: What role for international agricultural research? Outlook Agric. 2017, 46, 168-177. [CrossRef]

39. Giuliani, A.; Mengel, S.; Paisley, C.; Perkins, N.; Flink, I.; Oliveros, O.; Wongtschowski, M. Realities, perceptions, challenges and aspirations of rural youth in dryland agriculture in the Midelt Province, Morocco. Sustainability 2017, 9, 871. [CrossRef]

40. Eckert, E.; Turner, E.; Sallah, J.A.Y. Youth Rural-Urban Migration in Bungoma, Kenya: Implications for the Agricultural Workforce; RTI Press: Research Triangle Park, NC, USA, 2019.

41. FAO. African Youth in Agriculture, Natural Resources and Rural Development. Nat. Faune 2013, $28,1-91$.

42. IFAD. Feeding Future Generations_Young Rural People Today_Prosperous, Productive Farmers Tomorrow; IFAD: Rome, Italy, 2011.

43. Levin, J.; Milgrom, P. Introduction to Choice Theory. Available online: https://web.stanford.edu/ \{\}jdlevin/Econ\%20202/ Choice\%20Theory.pdf (accessed on 28 May 2021).

44. Benzaghta, M.A.; Elwalda, A.; Mousa, M.M.; Erkan, I.; Rahman, M. SWOT analysis applications: An integrative literature review. J. Glob. Bus. Insights 2021, 6, 54-72.

45. Shrestha, R.K.; Alavalapati, J.R.; Kalmbacher, R.S. Exploring the potential for silvopasture adoption in south-central Florida: An application of SWOT-AHP method. Agric. Syst. 2004, 81, 185-199. [CrossRef]

46. Lee, K.-L.; Lin, S.-C. A fuzzy quantified SWOT procedure for environmental evaluation of an international distribution center. Inf. Sci. 2008, 178, 531-549. [CrossRef]

47. Aldehayyat, J.S.; Anchor, J.R. Strategic planning tools and techniques in Jordan: Awareness and use. Strateg. Chang. 2008, 17, 281-293. [CrossRef]

48. Fleisher, C.S.; Bensoussan, B.E. Strategic, and Competitive Analysis: Methods and Techniques for Analyzing Business Competition; Prentice Hall: Upper Saddle River, NJ, USA, 2003.

49. Gürel, S.; Tat, M. SWOT Analysis: A Theoretical Review. J. Int. Soc. Res. 2017, 10, 994-1006. [CrossRef]

50. Amemiya, T. Qualitative Response Models: A Survey. J. Econ. Lit. 1981, 19, 1483-1536. 
51. Nair, G.S.; Astroza, S.; Bhat, C.R.; Khoeini, S.; Pendyala, R.M. An application of a rank-ordered probit modeling approach to the understanding level of interest in autonomous vehicles. Transportation 2018, 45, 1623-1637. [CrossRef]

52. Paudel, K.P.; Dunn, M.A.; Bhandari, D.; Vlosky, R.P.; Guidry, K.M. Alternative Methods to Analyze the Rank Ordered Data: A Case of Invasive Species Control. Nat. Resour. Modeling 2007, 20, 451-471. [CrossRef]

53. Cameroon, R.O. Stratégie Nationale de Développement 2020-2030: Pour la Transformation Structurelle et le Développement Inclusif, 2020. Available online: https:/ $/$ www.google.com/url?sa=t\&rct=j\&q=\&esrc=s\&source=web\&cd=\&cad=rja\&uact= 8\&ved=2ahUKEwj7jOCKiOzwAhVCOs0KHXuGC2AQFjAFegQICBAD\&url=https\%3A\%2F\%2Fdocuments.worldbank.org\% 2Fcurated\%2Fen\%2F661961475143883917\%2Fpdf\%2F105204-PUB-FRENCH-PUBLIC-PUBDATE-9-27-16Renforcer-les-comp\% 25C3\%25A9tences-au-Cameroun.pdf\&usg=AOvVaw1IDBo679SU4v-LmjOlfWCw\&cshid=1622194366881829 (accessed on 27 May 2021).

54. Majid, A.; Wesarat, P.-O.; Sharif, M. Role of Cultural Values in Career Choice: A Conceptual Framework, 2014. Available online: https:/ / www.researchgate.net/publication/281078426_Role_of_cultural_values_in_career_choice_A_conceptual_ framework/link/593969b74585153206122014/download (accessed on 27 May 2021).

55. Lobga, C. How to Register a Business in Cameroon. Available online: https:/ /openhubdigital.com/wp-content/uploads/2020/0 3/How-to-Register-a-Business-in-Cameroon.pdf (accessed on 27 May 2021).

56. FAO. FAO in Emergencies; FAO: Rome, Italy. Available online: http://www.fao.org/emergencies/countries/detail/en/c/153525 (accessed on 27 May 2021).

57. Kidido, J.K.; Bugri, J.T.; Kasanga, R.K. Dynamics of youth access to agricultural land under the customary tenure regime in the Techiman traditional area of Ghana. Land Use Policy 2017, 60, 254-266. [CrossRef]

58. Heckert, J.; Pereira, A.; Doss, C.; Myers, E.C.; Quisumbing, A. Structural Transformation, and Gendered Transitions to Adulthood among Rural Youth: Cross-National Evidence from Low- and Middle-Income Countries. J. Dev. Stud. 2021, 57, 614-634. [CrossRef]

59. IFPRI. The Effect of Land Inheritance on Youth Employment and Migration Decisions Evidence from Rural Ethiopia; IFPRI: Washington, DC, USA, 2016.

60. Jones, W.A.; Larke, A., Jr. Factors Influencing Career Choice Of African American And Hispanic Graduates Of A Land-Grant College Of Agriculture. J. Agric. Educ. 2001, 42. [CrossRef]

61. Amegnaglo, C.; Soglo, Y.; Akpa, A.; Oliveira, G. Determinants of Graduate Students' Participation in Agricultural Value Chain in Benin, 2014. Available online: https:/ / www.researchgate.net/publication/310130603_Determinants_of_Graduate_Students T1 \textquoteright_Participation_in_Agricultural_Value_chain_in_Benin/citation/download (accessed on 27 May 2021).

62. Etim, N.A.A.; Udoh, E.J. Willingness of Youths to Participate in Agricultural Activities: Implication for Poverty Reduction Email address. Am. J. Soc. Sci. 2018, 6, 1-5.

63. Fizer, D. Factors Affecting Career Choices of College Students Enrolled in Agriculture. Master's Thesis, The University of Tennessee, Martin, TN, USA, 2013.

64. Baliyan, S.P.; Nenty, H.J. Factors Underlying Attitude towards Agriculture as Predictors of Willingness to Enrol in the Subject by Senior Secondary Students in Botswana. J. Educ. Soc. Res. 2015, 5, 377. [CrossRef]

65. Mwaura, G.M. Just Farming? Neoliberal Subjectivities and Agricultural Livelihoods among Educated Youth in Kenya. Dev. Chang. 2017, 48, 1310-1335. [CrossRef]

66. Aphunu, A.; Atoma, C.N. Rural Youths' Involvement in Agricultural Production In Delta Central Agricultural Zone: Challenge To Agricultural Extension Development In Delta State. J. Agric. Ext. 2010, 14. [CrossRef]

67. Bhattacharjee, S.; Raj, S. Youth and ICTs for Agricultural Development; New India Publishing Agency: New Delhi, India, 2013; pp. 169-188.

68. Ken Lohento, O.D.A. ICT and Youth in Agriculture, 2015. Available online: http://gaaap.biz/documents/ICT-and-Youth-inAfrica.pdf (accessed on 27 May 2021).

69. YPARD. Youth in Extension: Are We Making the Most of Our Young Assets? Outcomes of YPARD and GFRAS e-discussion, 2011. Available online: https://ypard.net/sites/default/files/legacy_files/synthesis_outcomes-e-discussions-extension.pdf (accessed on 27 May 2021). 